\title{
【ワークショップ 1】
}

\section{ヒトを対象とした身体活動量・エネルギー消費量に関する最新研究を求めて}

ーブレスバイブレス法, ヒューマンカロリメータ, 二重標識水法, 加速度計で何ができるか? -

\author{
大河原 一 憲 \\ ((独)国立健康・栄養研究所 健康增進研究部)
}

\section{【趣旨】}

健康・スポーツ科学分野の研究において, 身体活動量 およびエネルギー消費量の評価は最も重要な測定項目の ひとつである。ヒトを対象に身体活動量およびエネル ギー消費量を高い精度で評価する方法には，ブレスバイ ブレス法, ヒューマンカロリメータ, 二重標識水法, 加 速度計法がある。ヒューマンカロリメータと二重標識水 法については, 近年日本国内で複数の研究施設に導入さ れ，関連機関の研究者らが中心にヒューマンカロリメー 夕協議会を立ち上げて情報共有をしつつ, 新たな知見が 得られるよう取り組み始めている。一方，世界に目を向 けると海外の研究機関からはすでにこれらの測定法を用 いたさまざまな成果が報告されている。そのため，今後 国際的に認められる成果をあげるためには，高い精度 を有する測定法で単に身体活動量やエネルギー消費量を 測るだけでは通用せず，各測定法の特徴を活かした斬新 な研究プロトコルを立案しなければならない。本ワーク ショップでは，ヒトの身体活動量およびエネルギー消費 量を高い精度で測定できる代表的な 4 つの方法を中心に それらの特徴を解説した上で，演者らが実際におこなっ た研究および関連する研究についてレビューし, 今後ど のような観点で研究プロトコルを立案するべきかディス カッションした。

【演者および発表概要】

1.ブレスバイブレス法

松尾知明

宇宙航空研究開発機構（JAXA）有人宇宙技術部

体力医学の研究分野ではブレスバイブレス法による 測定システムを備えた呼気ガス分析装置が様々な実験 で活用されている。本装置を用いた最近の報告には， 身体活動量計測器の妥当性を検討する研究, Exercise Economyに係る研究, 運動中や運動後の糖 ·脂質代謝 に係る研究, COPDやPAHなどの疾患の特徵と運動中の $\mathrm{VE}, \dot{\mathrm{VO}_{2}}, \mathrm{VCO}_{2}$ の動態とを絡めた研究などがある。機 器運搬面で利点のある本装置は, 国際宇宙ステーション にも持ち込まれ, 宇宙飛行士の最大酸素摂取量やエネル ギー必要量に係る研究にも活用されている。
2.ヒューマンカロリメータ

日比壮信

花王株式会社 ヘルスケア食品研究所

ヒューマンカロリメータを用いたエネルギー代謝測定 は，被験者の拘束が少ない状態での長時間連続測定が可 能であり，また，エネルギー消費量の測定と同時に基質 利用率 (呼吸商) も連続的に測定することができるとい う利点を持つ。一方，その測定にかかる時間や機器の高 額さなどから少人数を対象とした試験になることが多 く, 特長を生かした適切な研究デザインの設定が重要で ある。

3. 二重標識水法

引原有輝

千葉工業大学 工学部

二重標識水（DLW）法は, 日常生活下でのエネルギー 消費量を比較的正確に測定できる。使用する安定同位体 やその分析費用が高額なこともあり，国内での使用は一 部の研究機関や大学に限られている。そのため, 本邦の DLW法を用いた研究の例数は, 国外と比べると多いと は言えない状況にある。今後, 健康増進や肥満予防にお ける運動や日常生活活動の重要性についてDLW法と他 の評価法を併用したさらなる検討が望まれる。

4. 加速度計

\section{大河原一憲}

(独) 国立健康 ·栄養研究所 健康増進研究部 加速度計を用いて活動量を評価する利点は, 自由生活 下での活動タイプおよび活動強度を客観的に長時間評価 できることである。近年, 加速度值から日常生活活動, 歩行活動, スポーツなどに活動を判別するアルゴリズム が開発されており，新たな研究の可能性が見出されてい る。加速度計を用いた今後の研究課題としては，より細 かく分類された活動タイプと疾病の発症・予防との関係 や概年リズム・概日リズムと身体活動との関連などが考 えられる。 